- FINANSE I PRAWO FINANSOWE.

- Journal of Finance and Financial Law •

Grudzień/December 2017 • vol. 4(16): 37-46

https://doi.org/10.18778/2391-6478.4.16.04

\title{
PODATKOWE PREFERENCJE PRORODZINNE I ŚWIADCZENIA RODZINNE W REPUBLICE FEDERALNEJ NIEMIEC
}

\author{
Anna Franielczyk \\ Wydział Finansów i Ubezpieczeń \\ Uniwersytet Ekonomiczny w Katowicach
}

\section{Streszczenie}

We współczesnych gospodarkach ważną rolę w systemie opodatkowania dochodów ludności kreują preferencje związane niejednokrotnie z wydatkowaniem osiągniętego dochodu. Szczególnie istotną rolę $w$ tej kwestii odgrywają m.in. zwolnienia, odliczenia, których zastosowanie powoduje zmniejszenie podstawy opodatkowania lub wysokość samego podatku należnego. Najpopularniejszą wśród preferencji podatkowych jest ulga prorodzinna z tytułu posiadania bądź wychowywania dziecka (dzieci). Ulgi podatkowe pozytywnie wpływają na domowy budżet, gdyż zmniejszając ciężar podatkowy (podatek należny), stanowią dodatkowe źródło finansowania gospodarstw domowych. Niniejsza publikacja ma na celu analizę ulg i preferencji podatkowych oraz zasiłków rodzinnych w Republice Federalnej Niemiec oraz ustalenie ich wpływu na budżet państwa.

Słowa kluczowe: preferencje prorodzinne, ulgi podatkowe, zasiłki rodzinne, budżet państwa.

JEL Class: H2O, H24, H31. 


\section{WPROWADZENIE}

Większość państw zachodnich Unii Europejskiej ma bardzo dobrze ukształtowany system podatkowy. Jednym z celów polityki podatkowej tych państw jest zastosowanie odpowiednich instrumentów podatkowych, które wpłyną na realizację celów polityki społeczno-gospodarczej. Cechą charakterystyczną wymienionych państw jest dążenie do osiągnięcia idei sprawiedliwości społecznej w dziedzinie opodatkowania. Podatki w krajach zachodnich są instrumentem polityki gospodarczej, socjalnej, społecznej. O rozmiarze działalności publicznej finansowanej z budżetu państw Europy Zachodniej decyduje przede wszystkich polityka podatkowa. W związku z tym, że wszelkie ulgi i preferencje podatkowe w znaczny sposób wpływają na zmniejszenie dochodów budżetowych należy ustalić je na takim poziomie, aby spełniały funkcje pozafiskalne oraz zapewniały odpowiednie wpływy do budżetu [Wolański 2016: 325, 326]. Do katalogu podstawowych funkcji podatków zalicza się funkcję fiskalną, redystrybucyjną oraz stymulacyjną. Do realizacji ostatniej wymienionej funkcji, tj. stymulacyjnej, stosuje się metody takie jak ulgi czy zwolnienia, które stanowią ważne instrumenty oddziaływania na zachowania podatników [Podstawka 2011:174, 175]. W demokratycznym państwie prawa powszechność opodatkowania eliminuje istnienie zwolnień, przywilejów dla określonych grup społecznych, a zdolność podatkowa określona jest zasadą równego traktowania podatników. Oznacza to, że osoby posiadające taką samą zdolność podatkową powinny być opodatkowane tak samo, natomiast posiadające różną zdolność podatkową - w sposób zróżnicowany. Inny punkt widzenia tego aspektu przedstawia ustawodawca niemiecki, który nie przewiduje przykładowo możliwości skorzystania przez osobę samotnie wychowującą dziecko z łącznego opodatkowania zwanego potocznie w Polsce rozliczeniem z dzieckiem, tak jak ustawodawca polski. W zamian za to oferuje innego rodzaju zmniejszenia podatkowe [Litwińczuk: 58, 59].

Stosowane przez państwa UE ulgi mają zazwyczaj charakter odliczeń zmniejszających podstawę opodatkowania lub samego podatku. Należy przy tym nadmienić, iż ulgi podatkowe zorientowane głównie na zachowania podatników powodują także zmniejszenie wpływów podatkowych [Wyszykowski i Kasprzak 2016: 21, 25].

Publikacja skupiona została na przedstawieniu zasiłków rodzinnych będących elementem niemieckiego systemu świadczeń socjalnych i wybranych podatkowych preferencji prorodzinnych stanowiących część składową systemu podatkowego i społecznego oraz ustalenie ich wypływu na budżet państwa.

Celem artykułu jest ocena systemu podatkowego oraz systemu świadczeń socjalnych oraz identyfikacja czynników składających się na wymienione systemy i ustalenie ich wpływu na budżet państwa.

Analiza literatury oraz zmiennych statystycznych są zastosowanymi w publikacji metodami badawczymi. 


\section{RODZAJE I CHARAKTERYSTYKA PRORODZINNYCH PREFERENCJI PODATKOWYCH ORAZ WYBRANYCH ŚWIADCZEŃ RODZINNYCH W REPUBLICE FEDERALNEJ NIEMIEC}

Systemy podatkowe, które obecnie istnieją w krajach Europy Zachodniej powstały po drugiej wojnie światowej, a opodatkowanie dochodów obywateli stało się jednym z najważniejszych elementów umożliwiających realizację sprawiedliwości społecznej [Krajewska 2012: 88 ]. Poza możliwością łącznego opodatkowania ze współmałżonkiem, ustawodawstwo podatkowe krajów UE przewiduje różne inne możliwości biorące po uwagę stan rodzinny podatnika. Realizuje się to m.in. poprzez pomniejszenie dochodu o określoną kwotę przypadającą na każde dziecko. Kwoty uzależnione są m.in. od liczby dzieci oraz obowiązującego w danym państwie systemu podatkowego. Przykładowo w niektórych krajach UE zrezygnowano z rodzinnych ulg podatkowych i zastąpiono je świadczeniami socjalnymi [Krajewska 2012: 93]. Niemiecki system podatkowy, podobnie jak polski, przewiduje szereg preferencji podatkowych. Ulgi w podatkach dochodowych są nierozłącznym elementem konstrukcji samego podatku. Preferencje podatkowe $\mathrm{w}$ postaci ulg podatkowych umożliwiają pełnienie przez podatki m.in. funkcji pozafiskalnych. Chociaż skutkują z reguły zmniejszeniem lub obniżeniem ciężaru podatkowego, stając się korzystne dla podatnika, równocześnie powodują obniżenie dochodów publicznych.

Rząd Federalny Niemiec publikuje zbiory danych dla polityki podatkowej oraz szczegółowe raporty na wymieniony temat dotyczące subwencji budżetowych - subventionsbericht. Ostatnim raportem poruszającym wspomniane kwestie jest dwudziesty piąty raport federalny Niemiec na temat pomocy finansowej i korzyści podatkowych na lata 2013-2016 [Bericht der Bundesregierung] oraz zbiór danych dla polityki podatkowej edycja roku 2016-2017 [Datensammlung].

Analizując powyższe raporty można wywnioskować, że w Republice Federalnej Niemiec da się wyróżnić między innymi subwencje takie jak:

- finansowa pomoc publiczna - Finanzhilfen,

- preferencje podatkowe - Steuervergunstingungen.

Formy wsparcia, które zostaną poruszone w niniejszym artykule to Kindergeld czyli zasiłek rodzinny oraz Kinderfreibetrag, czyli podatkowa preferencja prorodzinna, na którą składa się ulga $\mathrm{z}$ tytułu opieki nad dzieckiem w celu zapewnienia dziecku potrzeb materialnych oraz ulga przeznaczona na potrzeby związane z zapewnieniem dziecku opieki, wychowania i wykształcenia.

Jednym z elementów mających znaczny wpływ na kształtowanie wydajności fiskalnej podatku dochodowego od osób fizycznych w Niemczech, jest wymieniona wyżej ulga na dzieci. Zgodnie z $§ 32$ ustawy o podatku dochodowym od osób fizycznych podatnikowi przysługuje prawo do skorzystania z Kinderfreibetrag, tj. ulgi na dziecko (dzieci) spokrewnione, jeżeli nie osiągnęło 18 roku 
życia, albo jeżeli ukończyło 18 rok życia, a nie ukończyło 21 roku życia pod warunkiem, że dziecko nie pozostaje w stosunku pracy i zarejestrowane jest w agencji pracy jako osoba poszukująca pracy, bądź nie ukończyło 25 roku życia i kształci się zawodowo. Podatnikowi przysługuje także ww. ulga na dziecko, które ze względu na niepełnosprawność fizyczną lub umysłową nie jest w stanie siebie utrzymać. Warunkiem w tym przypadku jest powstanie niepełnosprawności przed ukończeniem przez dziecko 25 roku życia [www 1]. W 2015 roku w RFN rodzic każdego dziecka w wieku do 18 roku życia miał prawo do skorzystania z ulgi podatkowej w kwocie 2256 EUR rocznie (tab. 1). W przypadku, gdy rodzice skorzystali ze wspólnego rozliczenia, kwota ta wyniosła 4512 EUR na dziecko (tab. 2) [www 2].

W 2016 roku ww. kwoty uległy zwiększeniu i obecnie wynoszą 2304 EUR dla rozliczających się indywidualnie oraz 4608 EUR dla rozliczających się wspólnie (tab. 2) [www 3].

$\mathrm{Za}$ ten sam okres niemieckiemu rodzicowi przysługuje także ulga z tytułu zapewnienia opieki i wychowania lub potrzeb nauki zawodu na dzieckiem w kwocie 1320 EUR dla rozliczenia indywidualnego oraz 2640 EUR dla rozliczenia wspólnego przez małżonków (tab. 2) [www 4].

Ulga na dziecko, jak i kwota wolna $z$ tytułu opieki i wychowania, są uwzględniane wyłącznie, gdy w wyniku analizy dokonanej przez niemiecki Urząd Skarbowy (Finanzamt) ww. ulgi będą korzystniejsze niż kwota Kindergeld (zasiłku rodzinnego) wypłaconego w bieżącym roku podatkowym, tj. oszczędność podatkowa jest większa niż kwota zasiłku [www 3].

Urzędnik niemieckiego „Finanzamt” przeprowadza tzw. test wydajności „Günstigerprüfung”, w wyniku którego określa, co dla podatnika jest korzystniejsze - zasiłek rodzinny czy ulga na dziecko. Test wykonywany jest $\mathrm{w}$ trakcie rozliczania przez organ podatkowy rocznego zeznania podatkowego.

Istnieje różnica pomiędzy zasiłkiem rodzinnym Kindergeld a ulgą na dziecko Kinderfreibetrag. Kindergeld nie wpływa na wysokość podatku, nie podlega opodatkowaniu i nie stanowi przedmiotu opodatkowania. Kindergeld jest zasiłkiem rodzinnym wpłacanym z funduszu rodzinnego budżetu państwa Familienkasse co miesiąc, a jego wysokość uzależniona jest od ilości posiadanych dzieci. Należy przy tym nadmienić, iż świadczenie to przysługuje osobom, którzy przebywają i legalnie pracują w Niemczech, czyli również obcokrajowcom. Kinderfreibetrag to z kolei podatkowa ulga na dzieci zmniejszająca podstawę opodatkowania. Preferencja ta powstaje w miesiącu urodzenia się dziecka i obowiązuje do momentu istnienia prawa do świadczeń opisanego w powyższej części artykułu. Urząd Skarbowy Finanzamt zwraca kwotę Kinderfreibetrag w zeznaniu rocznym. Należy przy tym nadmienić, iż podatnik nie może skorzystać z obydwu form jednocześnie [www 5]. 
Tabela 1. Dochody podatkowe z podatków pośrednich i bezpośrednich w Niemczech w latach 2010, 2015, 2016 oraz prognoza na lata 2017-2020

\begin{tabular}{|c|c|}
\hline Rok & Lączne dochody podatkowe [w mln EUR] \\
\hline 2010 & 530587 \\
\hline 2015 & 673261 \\
\hline 2016 & 695541 \\
\hline 2017 & 724532 \\
\hline 2018 & 751782 \\
\hline 2019 & 779001 \\
\hline 2020 & 806693 \\
\hline
\end{tabular}

Źródło: opracowanie własne na podstawie Datensammlung zur Steuerpolitik 2016-2017.

Tabela 2. Podatkowe preferencje prorodzinne i zasiłki rodzinne w Niemczech w latach 2010-2016

\begin{tabular}{|c|c|c|c|c|c|c|c|c|}
\hline$\frac{\ddot{\partial}}{2}$ & 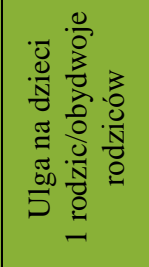 & 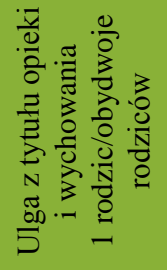 & 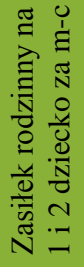 & 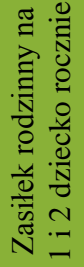 & 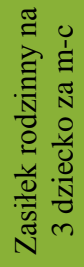 & 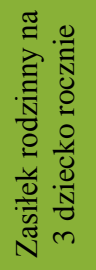 & 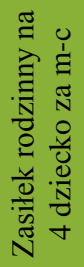 & 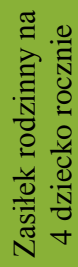 \\
\hline 2010 & $2184 / 4368$ & $1320 / 2640$ & 184 & 2208 & 190 & 2280 & 215 & 2580 \\
\hline 2011 & $2184 / 4368$ & $1320 / 2640$ & 184 & 2208 & 190 & 2280 & 215 & 2580 \\
\hline 2012 & $2184 / 4368$ & $1320 / 2640$ & 184 & 2208 & 190 & 2280 & 215 & 2580 \\
\hline 2013 & $2184 / 4368$ & $1320 / 2640$ & 184 & 2208 & 190 & 2280 & 215 & 2580 \\
\hline 2014 & $2184 / 4368$ & $1320 / 2640$ & 184 & 2208 & 190 & 2280 & 215 & 2580 \\
\hline 2015 & $2256 / 4512$ & $1320 / 2640$ & 188 & 2256 & 194 & 2328 & 219 & 2628 \\
\hline 2016 & $2304 / 4608$ & $1320 / 2640$ & 190 & 2280 & 196 & 2352 & 221 & 2652 \\
\hline
\end{tabular}

Źródło: opracowanie własne na podstawie danych Finanzamt Augsburg Land Einkommensteuer Gesetz (EStG), §32 Kinder, Freibeträge für Kinder, Kindergeld oraz Datensammlung zur Steuerpolitik 2016-2017.

Z przeglądu danych zawartych w tabeli 1 wynika, że roczne przychody z podatków w RFN wyniosły w 2015 roku prawie 675 mld EUR, z kolei szacunkowy przychód z podatków w roku 2020 powinien przekroczyć 800 mld EUR (zwiększenie o 125 mld EUR). 
Analizując wartości zawarte w tab. 2 stwierdza się, że podatkowe preferencje prorodzinne $\mathrm{w}$ kategorii ulgi na dziecko z roku na rok ulegają zwiększeniu, w odróżnieniu do ulgi z tytułu opieki i wychowania, która od ponad trzech lat pozostaje na stałym poziomie.

Analizując kwoty wypłacanych zasiłków rodzinnych (tab. 2) niezależnie od kategorii czy to zasiłku na pierwsze i drugie dziecko, czy trzecie i czwarte, można zauważyć, że od roku 2010 do roku 2014 kwoty te nie ulegały w ogóle zmianie. Modyfikacja kwoty nastąpiła dopiero w roku 2015. Wysokość zasiłku w tym roku wzrosła o 4 EUR w stosunku do lat 2010-2014.

\section{ZASIŁKI RODZINNE, ULGI I PREFERENCJE PODATKOWE JAKO CZYNNIKI WPŁYWAJĄCE NA WYDAJNOŚĆ FISKALNĄ BUDŻETU PAŃSTWA}

Na początku publikacji poddano pod analizę kwestię ustalenia wpływu zasiłków rodzinnych oraz prorodzinnych preferencji podatkowych na budżet państwa oraz sytuację gospodarstw domowych. Czy wybrane preferencje mają zasadniczy wpływ na budżet państwa w RFN? Aby odpowiedzieć na postawione pytanie należy zbadać, ile kosztują niemieckie państwo wyżej wymienione zasiłki rodzinne oraz preferencje podatkowe w postaci podatkowych ulg prorodzinnych.

Rząd Federalny Niemiec oraz Federalne Ministerstwo Finansów obliczają, jaka jest wartość wszystkich ulg, świadczeń, dotacji, subwencji udzielonych obywatelom oraz przedstawiają wyniki swych analiz w rocznych raportach. Dzięki raportom można określić jaka jest wartość przychodów budżetowych, jaki udział w przychodach rządu federalnego stanowią wpływy z podatku dochodowego. Sprawozdania te wyłaniają również kwoty wydatków budżetowych przeznaczonych na wsparcie rodzin oraz pomoc socjalną.

Przykładowo w roku 2014 w krajach Unii Europejskiej odliczenia od dochodu na każde dziecko z tytułu skorzystania z ulgi prorodzinnej wyniosły od 1510 EUR w Belgii do 7008 EUR w Niemczech. Z kolei odliczenia od samego podatku, na jedno dziecko $\mathrm{w}$ rodzinie $\mathrm{w}$ tym okresie kształtowały się od 265 EUR w Polsce do nawet 1200 EUR we Włoszech. Nadmienić przy tym należy, iż w krajach europejskich istnieją również inne ulgi mające charakter prorodzinny. Przykładowo we Francji wskazać można ulgę podatkową na cele edukacyjne oraz podobnie jak w Niemczech ulgę z tytułu opieki nad dzieckiem [Wyszykowski i Kasprzak 2016: 29].

Analizując kraje europejskie w kategorii wsparcia finansowego dla obywateli, czołówkę zajmują Luksemburg oraz Francja, przeznaczające rocznie na rodzinę odpowiednio 7304 EUR i 6772 EUR, a także Niemcy i Austria. Kata- 
log krajów europejskich zamyka Rumunia, Litwa, Grecja i Bułgaria przeznaczające dla rodzin pomoc finansową zaledwie w wysokości 500 EUR [www 6].

W kategorii bezpośredniej pomocy państw UE w dziedzinie ulg na dzieci i świadczeń rodzinnych średnia kształtuje się na poziomie 2246 EUR. Kwota ta została jednak zniekształcona przez wymieniony wyżej Luksemburg i Francję, a także przez Niemcy i Austrię, gdyż w rzeczywistości ponad 60\% państw UE nie osiąga tej wartości [www 6].

Porównując kraje europejskie pod względem polityki prorodzinnej, nie powinno się sugerować wyłącznie wsparciem oferowanym w postaci ulg prorodzinnych czy zasiłków na dzieci. W wielu państwach brak możliwości skorzystania z ww. świadczeń, kompensowany jest przykładowo możliwością wspólnego rozliczenia z małżonkiem, korzystania z bezpłatnych przedszkoli, książek (Finlandia, Szwecja) [www 6].

Szczegółowe zestawienie wydatków związanych z systemem świadczeń rodzinnych w RFN w latach 2010-2016 przedstawia tab. 3.

Tabela 3. Wydatki świadczeń rodzinnych w latach 2010-2016 - świadczenia dla dzieci (Kinderfreibetrag) oraz zasiłek rodzinny (Kindergeld) [w mln EUR]

\begin{tabular}{|c|c|c|c|c|c|c|c|c|}
\hline Kategoria & 2010 & 2011 & 2012 & 2013 & 2014 & 2015 & 2016 & Razem \\
\hline Kindergeld & 38820 & 38450 & 38540 & 38410 & 38510 & 39380 & 40210 & 272320 \\
\hline $\begin{array}{l}\text { Kinderfreie- } \\
\text { betrag }\end{array}$ & 2200 & 2320 & 2430 & 2510 & 2620 & 3080 & 3220 & 18380 \\
\hline Razem & 41020 & 40770 & 40970 & 40920 & 41130 & 42460 & 43430 & 290700 \\
\hline $\begin{array}{l}\text { W tym: } \\
\text { Zwolnienia } \\
\text { dot. docho- } \\
\text { dów poniżej } \\
\text { średniej } \\
\text { krajowej } \\
\text { (minimum } \\
\text { egzystencji) }\end{array}$ & 21860 & 22400 & 23070 & 23430 & 23920 & 24350 & 25130 & 164160 \\
\hline $\begin{array}{l}\text { W tym: } \\
\text { Dofinanso- } \\
\text { wania } \\
\end{array}$ & 19160 & 18370 & 17900 & 17490 & 17210 & 18110 & 18300 & 126540 \\
\hline
\end{tabular}

Źródło: opracowanie własne na podstawie Bundesfinanzministerium - Datensammlung zur Steuerpolitik, Ausgabe 2015, 2016-2017. Daten zum Familienleistungsausgleich.

Analizując dane ujęte w tab. 3 wynika, że największy wydatek państwa na pokrycie świadczeń rodzinnych w RFN stanowi zasiłek rodzinny - Kindergeld. W latach 2010-2016 kosztował państwo prawie 272500 mln EUR (tab. 3). Po- 
równując dane statystyczne odnotowujemy mniejsze wpływy z podatku dochodowego na skutek skorzystania przez podatników z ulgi na dzieci. Kinderfreibetrag kosztował niemieckie państwo prawie $18400 \mathrm{mln}$ EUR, tj. 16-krotnie mniej niż Kindergeld (tab. 3). Z analizy powyższych danych wynika, że w efekcie zwiększenia miesięcznej kwoty Kindergeld, w 2015 roku wydatki w ciągu roku zwiększyły się o 870 mln EUR w stosunku do roku 2014 (tab. 3). Należy przy tym nadmienić, iż w związku ze zwiększeniem w 2016 roku kwot zasiłku rodzinnego o 2,00 EUR na każde dziecko wydatki budżetowe zwiększyły się o 830 mln EUR w porównaniu do roku 2015 oraz o 1700 mln EUR w stosunku do roku 2014.

Tabela 4. Wydatki zasiłku rodzinnego (Kindergeld) na pierwsze i kolejne dzieci w latach 2010-2015 [w mln EUR]

\begin{tabular}{|l|r|r|r|r|r|r|r|}
\hline Kindergeld Rok & \multicolumn{1}{|c|}{2010} & \multicolumn{1}{c|}{2011} & \multicolumn{1}{c|}{2012} & \multicolumn{1}{c|}{2013} & \multicolumn{1}{c|}{2014} & \multicolumn{1}{c|}{2015} & \multicolumn{1}{c|}{2016} \\
\hline Pierwsze dziecko & 10563 & 10476 & 10494 & 10454 & 10500 & 10497 & 10606 \\
\hline Drugie dziecko & 5158 & 5108 & 5126 & 5109 & 5113 & 5119 & 5172 \\
\hline Trzecie dziecko & 1300 & 1287 & 1294 & 1292 & 1288 & 1297 & 1311 \\
\hline $\begin{array}{l}\text { Czwarte i kolejne } \\
\text { dziecko }\end{array}$ & 443 & 427 & 426 & 427 & 424 & 430 & 435 \\
\hline Razem & 17464 & 17298 & 17340 & 17282 & 17325 & 17343 & 17524 \\
\hline
\end{tabular}

Źródło: opracowanie własne na podstawie Bundesfinanzministerium - Datensammlung zur Steuerpolitik, Ausgabe 2015, 2016-2017, Daten zum Familienleistungsausgleich.

Po przeprowadzeniu analizy kosztów zasiłku rodzinnego, jakie ponosi niemieckie państwo według kryteriów podziału na pierwsze i kolejne dzieci wynika, że najwięcej nakładów pieniężnych zostało przeznaczonych na wsparcie rodzin $\mathrm{z}$ jednym dzieckiem. Wydatki te utrzymują się na podobnym poziomie od pięciu lat i kosztują rząd ponad 10000 mln EUR rocznie. Z obserwacji danych wynika, że z zasiłku rodzinnego korzystna najmniej rodzin wielodzietnych i cena jaką ponosi państwo na ten cel oscyluje w kwocie ok. 400 mln EUR rocznie (tab. 4).

W roku obrotowym 2016 przychody rządu federalnego Niemiec wyniosły ponad 316 mld EUR i były wyższe o 5,8 mld EUR, tj. 1,9\% w stosunku do roku 2015 (tab. 5). W okresie tym wydatki na Kinderfreibetrag kosztowały niemieckie państwo prawie 40 mld EUR, a wydatki na zasiłek rodzinny Kindergeld 3 mld EUR (tab. 3). W ogólnej kwocie przychodów budżetowych wpływy z podatku dochodowego wyniosły w 2016 roku prawie 22,9 mld EUR, co oznacza, że pokrywają zaledwie połowę wydatków związanych z ulgą prorodzinną Kinderfreibetrag. Przychody podatkowe ogółem zasiliły budżet państwa w poprzednim roku o kwotę 289 mld EUR, z czego wpływy z podatku dochodowego stanowily niecałe $9 \%$ tej kwoty. 
Tabela 5. Przychody rządu federalnego Niemiec w latach 2015-2016

\begin{tabular}{|l|r|r|r|r|r|}
\hline $\begin{array}{l}\text { Rodzaj } \\
\text { przychodu }\end{array}$ & 2015 & $\begin{array}{c}2016 \\
\text { Stan obecny } \\
\text { [w mln EUR] }\end{array}$ & $\begin{array}{c}2016 \\
\text { Stan oczekiwany } \\
\text { [w mln EUR] }\end{array}$ & $\begin{array}{l}\text { Odchylenie od } \\
\text { poprzedniego } \\
\text { roku } \\
\text { [w mln EUR] }\end{array}$ & $\begin{array}{c}\text { Odchylenie } \\
\text { od poprzed- } \\
\text { niego roku } \\
\text { [w \%] }\end{array}$ \\
\hline $\begin{array}{l}\text { Lączne przycho- } \\
\text { dy budżetowe }\end{array}$ & 311055 & 316829 & 310515 & 5774 & 1,9 \\
\hline $\begin{array}{l}\text { W tym: } \\
\text { przychody po- } \\
\text { datkowe }\end{array}$ & 281706 & 288991 & 288083 & 7285 & 2,6 \\
$\begin{array}{l}\text { W przychodach } \\
\text { podatkowych } \\
\text { przychody } \\
\text { z podatku } \\
\text { dochodowego }\end{array}$ & 20647 & 22879 & 21144 & 2232 & 10,8 \\
\hline
\end{tabular}

Źródło: opracowanie własne na podstawie Monatsbericht des BMF.

Z analizy powyższych danych wywnioskować można, że ulgi prorodzinne (tj. Kinderfreibetrag) oraz zasiłki rodzinne (tj. Kindergeld) wywierają znaczny wpływ na wydajność fiskalną państwa. Nadmienić przy tym należy, że świadczenia te nie pokrywają $\mathrm{w}$ pełni wpływów $\mathrm{z}$ podatku dochodowego, w ramach którego są rozliczane. $Z$ kolei biorąc pod uwagę przychody podatkowe ogółem, koszty związane z polityką prorodzinną stanowią $14 \%$ tych przychodów.

\section{PODSUMOWANIE}

Z interpretacji zebranego materiału można wywnioskować, że niemiecki rząd posiada bardzo dobrze rozwinięty system pomocy państwa we wspieraniu rodzin. Korzystne ulgi podatkowe oraz zasiłki rodzinne i inne świadczenia pomocowe, to narzędzia stosowane przez niemiecki rząd m.in. w celach prodemograficznych. Na podstawie analizy literatury oraz analizy zmiennych statystycznych można wywnioskować, że podatkowe preferencje prorodzinne i świadczenia rodzinne odnoszą znaczny wpływ i rzutują na budżet państwa. Wymienione w publikacji w kategorii wsparcia finansowego kraje członkowskie UE, plasują Niemcy w czołówce państw oferujących rodzinom wsparcie finansowe. W powyższej publikacji nadmieniono, iż jedna $\mathrm{z}$ form wsparcia $\mathrm{w}$ postaci zasiłku rodzinnego Kindergeld jest świadczeniem przysługującym osobom pracującym legalnie i przebywającym na terenie Niemiec. W związku z powyższym osoby te mogą ubiegać się o ww. świadczenie w kwotach przysługujących Niemcom. 


\title{
BIBLIOGRAFIA
}

Bericht der Bundesregierung über die Entwicklung der Finanzhilfen des Bundes und der Steuervergünstigungen für die Jahre 2013 bis 2016, 25. Subventionsbericht.

Datensammlung zur Steuerpolitik, Ausgabe 2015.

Datensammlung zur steuerpolitik 2016-2017.

Einkommensteuergesetz (EStG), 16.10.1934, §10, §24a, §32 (BGBI I s. 1914).

Monatsbericht des BMF.

Krajewska A., 2012, Podatki w Unii Europejskiej, PWE, Warszawa.

Litwińczuk H., Prawo podatkowe przedsiębiorców, Dom Wydawniczy ABC.

Podstawka M., 2011, Podstawy finansów teoria i praktyka, SGGW, Warszawa.

Wolański R., 2016, System podatkowy w Polsce, Wolters Kluwer, Warszawa.

Wyszykowski W., Kasprzak P., 2016, Ulga podatkowa jako instrument realizacji pozafiskalnych funkcji podatków, „Zarządzanie Finansami i Rachunkowość”, nr 4, SGGW, Warszawa.

[www 1] § 32 Eiknommensteuergesetz, www.gesetse-im-internet.de.

[www 2] Niemcy-wyższa-kwota-od-podatku-oraz-kindergeld Job profi.pl/plaktualności/

polityk/1680 oraz Datensammlung zur steuerpolitik 2016-2017.

[www 3] www.zwrot-holandia.pl/niemcy.html oraz Datensammlung zur steuerpolitik 2016-2017.

[www 4]//biznes.onet.pl/wiadomości/analizy/analizy-podatkowe/nowe-rozwiązania-w-uldze

-prorodzinnej-od-2015-roku oraz Datensammlung zur steuerpolitik 2016-2017.

[www 5] Wie funktioniert das mit dem Kinderfreibetrag?, www.vhl.de.

[www 6] www.pwc.pl - Ulgi podatkowe i świadczenia rodzinne w UE, Raport 2016.

\section{FAMILY-FRIENDLY TAX PREFERENCES AND CHILD BENEFITS IN THE FEDERAL REPUBLIC OF GERMANY}

\begin{abstract}
In contemporary economies an important part in tax revenue system is frequently played by preferences associated with expending a gained income. Particularly essential in this matter are exemptions and tax advantages which cause tax base reduction or tax payable reduction. The most common among tax preferences is dependency exemption for those who have or raise child/children. Tax deductions have got a positive impact on household budget as they reduce tax payable and are an additional household financial source.

In this paper we aim at analysing family-friendly tax deductions and preferences as well as family allowance in the Federal Republic of Germany and determining their influence on state budget.
\end{abstract}

Keywords: family-friendly preferences, tax deductions, family allowance, state budget. 